Society and Economy 36 (2014) 1, pp. 37-68

DOI: 10.1556/SocEc.36.2014.1.4

\title{
WHY ARE CIVIL LIBERTIES MORE IMPORTANT THAN EXECUTIVE CONSTRAINTS IN ECONOMIC DEVELOPMENT? A PROPERTY RIGHTS APPROACH ${ }^{1}$

\author{
PÁL CZEGLÉDI \\ Associate professor, Faculty of Economics and Business Administration, University of Debrecen \\ E-mail:pal.czegledi@econ.unideb.hu
}

This paper develops a simple model that helps understand an important fact concerning cross-country pattern of growth and institutions shown by BenYishay and Betancourt (2010). They show that civil freedoms, especially one of their components called Autonomy and Individual Rights, are more important determinants of economic development than constraints on executives, a widely used measure in the literature on institutions and growth. The paper provides an interpretation of this fact through the lense of an argument that puts emphasis on three insights. The first is that civil freedoms can be seen as property rights broadly understood. The second is that with a higher scope of property rights enforced, the government must be able to commit to a lower level of expropriation of income. Third, institutions of freedom are sticky: they must be in line with the culture of the country so that they can be enforced with a reasonable cost. By addressing this specific question of constraints on executives versus civil freedoms the paper joins the literature which emphasizes the importance of culture in economic development.

Keywords: civil liberties, property rights, development

JEL codes: $\mathrm{P} 14, \mathrm{P} 16, \mathrm{O} 11$

The paper was supported by the János Bolyai Research Scholarship of the Hungarian Academy of Sciences. The author wishes to thank two anonymous referees for their genuinely helpful comments on numerous points of the paper and for their suggestions that substantially improved the paper. Any remaining errors are those of the author. 


\section{INTRODUCTION: CONSTRAINT ON EXECUTIVES OR CIVIL LIBERTIES?}

Economists are a long way from agreement on the role of democracy in economic development. There are some widely accepted claims, however. One of them, at least in what I call the mainstream of institutional research, ${ }^{2}$ is that the checks and balances which the democratic institutions are able to create are the fundamental determinants of economic development. That is because these checks and balances constrain political power, and these constraints are able to contain the risk of expropriation, and, so the argument goes, a low risk of expropriation is necessary for investment in physical and human capital, and most of all, for innovation. Indeed, Acemoglu and Johnson (2005) found that property rights institutions, measured as the "constraint on executive", are more important determinants of economic development than "contracting institutions" which in the long run do not even really matter. Since then, "constraints on executives" as documented in the Polity IV database have become the most important measure of the security of property rights, and of institutions in general, especially in the literature searching for institutional causes of economic development.

This is why the empirical result derived by BenYishay and Betancourt (2010) is fundamentally important for an understanding of the question as to how political institutions, market institutions, and economic development relate to each other. They show in a cross-sectional analysis of 60 countries that civil freedoms, and especially the part of it called by Freedom House (2012) Autonomy and Individual Rights, perform better in terms of explanatory power and statistical significance than the widely used constraints on executives measure does. This is true even if control variables are included and reverse causation is controlled by a 2SLS method.

The interpretation of this important fact may not be clear-cut, though. As I will show, in section 2, there are at least three approaches to understanding the causal mechanisms between democratic institutions and economic development. My own interpretation - which is intended to be the contribution of this paper - is inspired by the insight that, as emphasized by Sobel and Coyne (2011: 121), civil liberties "capture many elements of embedded informal institutions, including traditions, religion, and customs".

Based on this insight this paper is aimed at building an argument that is helpful in understanding BenYishay and Betancourt's (2010) result concerning the im-

2 See the next section for a more detailed elaboration of what is meant by this. Kozenkow (2013) provides a brief but very good overview of New Institutional Economics including the main conclusions of the empirical research cited here and the property rights approach applied in the paper.

Society and Economy 36 (2014) 
portance of civil freedoms in economic development as compared to that of executive constraints. The argument is that this fact can be traced back to three characteristics of institutions of individual freedom. First, a higher level of freedom means that the government must be able to commit itself to a lower level of expropriation. Second, institutions of freedom (civil as well as economic) are sticky, that is, they have to be in line with culture. Third, civil freedoms can be seen as the enforcement of a relatively broad scope of property rights. On an abstract level, economic freedoms and civil freedoms are not really different. The paper shows that when these three assumptions are put together in a simple model they are able to explain why civil freedom is a better "predictor" of development than executive constraints are.

This argument will be presented in the following steps. The next section briefly reviews the literature on the three different explanations concerning the relationship between economic development and civil liberties or democracy, and describes the broad approach applied in the paper. Section 3, though not intended to be a literature review, makes an extensive use of the literature on the similar nature of economic and civil freedoms with the help of which I provide an interpretation of civil liberties in the framework of property rights. Using this framework, in section 4 I develop a very simple model of how constraints on executives, culture, and technology affect the provision of civil liberties. Section 5 uses this model to understand the different effect of executive constraints and civil liberties on development. Section 6 draws some conclusions.

\section{POLITICAL RIGHTS, CIVIL FREEDOM AND ECONOMIC DEVELOPMENT - A BRIEF LITERATURE REVIEW}

Seeing economic development and democracy as two variables ${ }^{3}$ which are correlated in time as well as across countries, there are logically three possibilities to model their relationship. The first is to say that it is democracy that causes development. The second is to say that it is just the other way around and development causes democracy. The third possibility is to say that there are third factors that

The work concentrating on this question sees "democracy" as a mix of different institutions providing political rights and civil liberties. These rights and liberties are theoretically different, but they are very closely associated empirically. This may be the reason why most of the studies cited do not really emphasize the difference between political rights, civil liberties, and the institutions that make them possible. In the studies reviewed below it is often "democracy" that is used as a variable, which includes civil liberties. That is the reason I will not limit this overview only to those works that discuss civil liberties in a narrow sense. 
make both variables go in step with each other. All the three views are represented in the economics literature (see Table 1).

The first explanation - the one that can be viewed as the institutional mainstream - claims that as democratic institutions are constraints on the political elite they reduce the risk of expropriation (North - Weingast 1989; Olson 2000; Acemoglu et al. 2005). This view has been given much support in the past decade by showing that the most important institutions in economic development are those that constrain political power (Acemoglu et al. 2001; Acemoglu - Johnson

Table 1

4 Although McCloskey (2010) does not directly address the "democracy and development" issue, she emphasizes that modern economic growth was caused by a new ideology giving dignity to

Three approaches to the relationship between economic development and democracy

\begin{tabular}{|c|c|c|c|}
\hline Questions & $\begin{array}{l}\text { Institutional } \\
\text { mainstream }\end{array}$ & $\begin{array}{c}\text { Lypset hypothesis } \\
\text { (modernization thesis) }\end{array}$ & $\begin{array}{c}\text { Culture and } \\
\text { technology view }\end{array}$ \\
\hline $\begin{array}{l}\text { Interpretation } \\
\text { of causality }\end{array}$ & $\begin{array}{l}\text { Democratic institu- } \\
\text { tions cause develop- } \\
\text { ment }\end{array}$ & $\begin{array}{l}\text { Development leads to } \\
\text { democracy }\end{array}$ & $\begin{array}{l}\text { Development and } \\
\text { democracy go step by } \\
\text { step as a result of third } \\
\text { factors }\end{array}$ \\
\hline $\begin{array}{l}\text { Role of civil } \\
\text { liberties }\end{array}$ & $\begin{array}{l}\text { Civil liberties con- } \\
\text { strain executives }\end{array}$ & $\begin{array}{l}\text { Civil liberties are } \\
\text { luxury goods }\end{array}$ & $\begin{array}{l}\text { Civil liberties are } \\
\text { important for } \\
\text { constitutional exchange }\end{array}$ \\
\hline $\begin{array}{l}\text { Role of execu- } \\
\text { tive constraints }\end{array}$ & $\begin{array}{l}\text { Constraints on execu- } \\
\text { tives lower the risk of } \\
\text { expropriation }\end{array}$ & $\begin{array}{l}\text { Constraints are de- } \\
\text { manded as a result of } \\
\text { better education and } \\
\text { higher income }\end{array}$ & $\begin{array}{l}\text { Executive constraints } \\
\text { can be seen as a result } \\
\text { of constitutional } \\
\text { exchange fuelled by } \\
\text { new elite interest an } \\
\text { ideology }\end{array}$ \\
\hline $\begin{array}{l}\text { Role of } \\
\text { "culture" }\end{array}$ & Culture has no role & $\begin{array}{l}\text { Culture may impede } \\
\text { the process in which } \\
\text { development brings } \\
\text { about democracy }\end{array}$ & $\begin{array}{l}\text { "Ideology" is needed } \\
\text { for liberal economic } \\
\text { and political reforms }\end{array}$ \\
\hline $\begin{array}{l}\text { Leading } \\
\text { authors and } \\
\text { works }\end{array}$ & $\begin{array}{l}\text { Acemoglu - Robinson } \\
(2012) \\
\text { North - Weingast } \\
(1989)\end{array}$ & $\begin{array}{l}\text { Lipset (1959) } \\
\text { Barro (1996) } \\
\text { Paldam - Gundlach } \\
\text { (2008) } \\
\text { Gleaser et al. (2004) }\end{array}$ & $\begin{array}{l}\text { Congleton (2011) } \\
\text { McCloskey }(2010)^{4}\end{array}$ \\
\hline
\end{tabular}

Note: This table summarises the literature review of section 2. bourgeois life. The latter, I think, is a first step towards developing democratic institutions. 
2005); that it is democracy that comes first, not development or human capital accumulation (Acemoglu et al. 2005a, b); and that in non-democratic societies the elite can block the introduction of new technologies that would lead to economic development because they fear the political uncertainties that it might bring (Acemoglu - Robinson 2006).

The view that emphasizes the causality running from development to democracy is usually called Lipset's hypothesis (Lipset 1959; Barro 1996; Paldam 2007). According to this view (Paldam - Gundlach 2008) economic development and human capital accumulation closely associated with it will cause an increasing demand for democratic institutions. Paldam's (2007) analysis gives support to this view, also referred to as the "grand transition", and to some of the accompanying cultural approaches, although he does not find it relevant that democracy causes growth. This is broadly the same conclusion reached in several other papers (e.g. Paldam - Gundlach 2008, 2012).

Put differently, it is absolutely not clear that there is any causality running from political or civil freedom towards development. Paldam and Gundlach (2012) use Granger regressions and different instrumental variables to compare short- and medium-run effects with long-run effects and find that in the long run the causality that runs from income to democracy is almost overwhelming, while the reverse effect can only be detected in the short run (3 years). They also use variables of the cultural kind and conclude that some of them - such as the share of Protestants and Muslims within the population - matter. Using historical data on schooling Murtin and Wacziarg (2012) also reaffirm the Lipset hypothesis and find no evidence of a causality running from democracy to development.

This grand transition thesis is also echoed by those theories and empirical studies of economic development (Gleaser et al. 2004; Easterly - Levine 2012) that show that long-run economic development was determined to a large extent by human capital and probably culture and not by the strategies of colonization (or the initial natural conditions by which it was affected) and by the different political institutions they resulted in, as is suggested by the first view.

It is possible to formulate a third view emphasizing different third factors when explaining the co-movement of democratic institutions and development. Some researchers have done so. As we have just seen, Paldam (2007) cannot reject entirely the idea that culture can account for the development of democracy at least partially, and on the other hand some economists (e.g. Tabellini 2010) also emphasize the role of culture in economic development. Indeed, Sobel and Coyne (2011) show, as we saw in section 1, that different institutions are closely related and civil liberties most probably reflect some deep-seated cultural element.

In his book on constitutional development in the West, Congleton (2011) explains that a liberal ideology was one of the driving forces of democratization, to- 
gether with the new economic interests and political pressures created by economic development which were made possible by the liberal economic reforms. Beside detailed historical case studies of the countries in question he applies Granger causality tests of the time series data of these countries (Congleton 2011: 573-610) and his conclusion of the "bootstrapping" nature of political and economic processes are supported by the mutual determination of development and democracy.

The three assumptions made in the introduction are echoed in these approaches - although not all of them are embraced. The first one is included in all three approaches: no one denies that for innovation to happen a low risk of expropriation is needed. The role of culture or ideology is considered in the third approach as a condition of a constitutional exchange the result of which is a higher level of freedom. The third assumption is, however, not really emphasized by any of these approaches. This is why I consider the application of the property rights view to be the contribution made by this paper. The next section elaborates on this third assumption.

\section{FREEDOM AS THE SCOPE AND ENFORCEMENT OF PROPERTY RIGHTS ${ }^{5}$}

My interpretation of the fact described in the introduction rests on three assumptions. Namely I assume that (1) a higher level of freedom means that the government must be able to commit itself to a lower level of expropriation, but (2) the institutions of freedom (civil as well as economic) have to be in line with culture, and (3) civil freedoms can be seen as the enforcement of a relatively broad scope of property rights. In this section I will try to show how these assumptions can be integrated by applying the approach of the so called property rights school.

Assumption (3) can be derived by recognizing that labelling some rights "property" and others "civil" is an arbitrary way of thinking in this approach. Hence an application of this way of thinking makes it possible to see "economic freedoms" and "civil freedoms" in a unified framework.

In this classical liberal interpretation there is no fundamental difference between economic freedom and civil freedom. In accordance with my assumption (1) freedom is defined as an absence of coercion (Hayek 1960: 11-21). More precisely, some level of coercion is always present, because some coercion is needed to enforce the rules ensuring freedom. Freedom is at its maximum, when coercion

5 This section develops further the argument I present in Czeglédi (2012) where I propose that the difference between economic and civil freedom are vague and arbitrary and this has implications when we look at these freedoms as determinants of the wealth of countries. 
- including private coercion - is at its minimum. While, for example F. A. Hayek is generally seen as a champion of economic freedom, in one of his magnum opuses he came to the conclusion that

[t]he importance of freedom [...] does not depend on the elevated character of the activities it makes possible. Freedom of action, even in humble things, is as important as freedom of thought. It has become a common practice to disparage freedom of action by calling it "economic liberty". But the concept of freedom of action is much wider than that of economic liberty, which it includes; and what is more important, it is very questionable whether there are any actions which can be called merely "economic" and whether any restrictions on liberty can be confined to what are called merely "economic" aspects. Economic considerations are merely those by which we reconcile and adjust our different purposes, none of which, in the last resort, are economic (excepting those of the miser or the man for whom making money has become an end itself) (Hayek 1960: 35).

The same view is formulated by Knight (1922: 472) when he says that

[t]he idea of a distinction between economic wants and other wants must be abandoned. There is no definable objective, whether subsistence, gratification of fundamental impulses or pleasure, which will serve to separate any of our activities from the body of conduct as a whole.

That is, there is no way to decide whether a certain kind of human action is "economic" or not. However, if this decision is impossible, it is also impossible to decide whether a certain kind of freedom is "economic" or not, since this label should describe the action that it makes possible.

Instead of talking about economic and civil freedom, it makes more sense to talk about two dimensions of freedom, the enforcement of rights and the scope of rights. The difference between these two dimensions of property rights can be derived from the "property rights approach" (Alchian and Demsetz 1973). Alchian and Demsetz (1973: 17) give a very concise description of what is meant by property rights in this tradition when they say that "[w]hat are owned are socially recognized rights of action", that is, "[w] hat is owned are rights to use resources, including one's body and mind, and these rights are always circumscribed, often by the prohibition of certain actions" (emphasis in original). It is clear that from this perspective civil rights are property rights. As Barzel (1989: 2, footnote 1) makes it explicit, "[h]uman rights are simply part of people's property rights. Human rights may be difficult to protect or to exchange, but so are rights to many other assets."

6 BenYishay and Betancourt (2010: 284) mention as well that "the protection of human rights [...] follows the same logic" of property rights defined as the "right to consume services of, the right to generate income from and the rights to alienate an asset". 
From this point of view it would require us to define those rights that are economic to get a measure of economic freedom, and, similarly one should be able to define "civil use" of an asset to get a measure of civil liberties. It is not clear whether there is a general criterion to make this categorization. Gwartney and Lawson (2003: 408) argue that economic freedom reflects a "different sphere of human interaction", although "the foundation of political and civil liberty is identical to that of economic freedom." But they do not provide the reader with a general concept to establish a difference.

Such a criterion might come from Vanberg (2001: 23). He proposes that the definition of property rights given above confuses two different dimensions of property rights which he calls "the issue of assigning rights" which answers the question "who owns what?" and the "issue of defining rights" which answers the question of "what does it mean to own something?". By this taxonomy Vanberg (2001) is clarifying the difference between the view of laissez faire liberalism and that of constitutional liberalism. Laissez faire liberals put great emphasis on the assigning issue, most importantly, that of assigning rights between the state and private players. This is roughly the way Gwartney and Lawson (2003: 406) argue, too, writing that "[i]nstitutions and policies are consistent with economic freedom when they provide an infrastructure for voluntary exchange, and protect individuals and their property from aggressors seeking to use violence, coercion, and fraud to seize things that do not belong to them". Clearly this definition is based on the question "who owns what?" and not on the meaning of ownership, since one is supposed to know what it means that something "belongs to someone". This allows us to interpret economic freedom as a measure of the extent to which the government in a country is reallocating property rights from its original owner to someone else. As shown by the construction of the Economic Freedom of the World index (Gwartney et al. 2012) or the Index of Economic Freedom (Miller et al. 2012) this could happen through direct redistribution, by a legal system and regulation that discriminates or that works with high transaction costs, by inflation, by restrictions on international trade, and on business inside the borders. ${ }^{7}$

The two Vanbergian dimensions are, however, implicitly included in the classical article by Alchian (1977[1965]: 130) which claimed that (emphasis added)

The Fraser Institute's Economic Freedom of the World Index has five areas: (1) size of government, (2) legal structure and the security of property rights, (3) access to sound money, (4) freedom to trade internationally, and (5) regulation of credit, labour and business. See Gwartney et al. (2012) for a more detailed exposition of these areas. The Index of Economic Freedom of the Heritage Foundation aggregates ten freedoms: property rights, freedom from corruption, fiscal freedom, government spending, business freedom, labour freedom, monetary freedom, trade freedom, investment freedom, financial freedom. See Miller et al. (2012) for a more detailed exposition of these areas.

Society and Economy 36 (2014) 
[b]y a system of property rights I mean a method of assigning to particular individuals the "authority" to select for specific goods, any use from a nonprohibited class of uses. ... the concepts of "authority" and "non-prohibited" rely on some concept of enforcement or inducement to respect the assignment and scope of prohibited choice.

Vanberg's (2001) two dimensional theoretical structure may be useful to differentiate civil liberties from economic freedom. I suggest applying a simple structure according to which economic freedom refers to the allocation of rights between the state and the private players while civil liberties are mainly about the scope of rights that are "socially recognized". For example, by putting heavy restriction on business, the government is re-allocating income from consumers to some privileged group. But if it is the freedom of expression that is restricted then no private player can use their own asset to express ideas which government officials do not like. This is in line with the general expression of human rights according to which "human rights as we know them today are mainly political norms dealing with how people should be treated by their governments and institutions" (Nickel 2013). I do not claim that every kind of human right fits the property rights approach. It is only individual and negative rights that do. This is why I confine the discussion to civil liberties and not human rights. ${ }^{8}$

Freedom of expression seems to be a good example to explain the idea that the enforcement of freedom (assignment of rights) is a separate decision from the definition of rights. As it is expressed in the United Nations' Universal Declaration of Human Rights (1948), "[e]veryone has the right to freedom of opinion and expression; this right includes freedom to hold opinions without interference and to seek, receive and impart information and ideas through any media and regardless of frontiers". Regarding that some persuasion is included in every sector of the economy, some persuasion is needed for every market transaction (McCloskey Klamer 1995). ${ }^{9}$ The market can be seen as a social space with perpetual conversation between the players (Storr 2008). As Storr (2008: 148) concludes "erecting trade barriers also locks off potential conversations and access to potential dialogical partners". This means that you cannot weaken the enforcement of economic freedom alone, because the market is a "social space" where both "commercial" and "non-commercial" activities take place. By preventing some trading

In addition, civil liberties must be seen as different from political rights. The fact that these two sets of rights are conceptually different is expressed, for example, in the views held by some great classical liberal thinkers who supported civic freedom fully but were not democrats at all (Director 1964: 3-4).

9 Note also, that Sen (1999: 6.) uses a similar example to illustrate the point of a freedom-centred normative argument when he writes that "[ $[\mathrm{t}]$ he freedom to exchange words, or goods, or gifts does not need defensive justification in terms of their favourable but distant effects; they are part of the way human beings in society live and interact with each other (unless stopped by regulation or fiat)". 
you will prevent some talking. Once it is decided what scope of rights are non-prohibited, it becomes very hard to enforce various groups of property rights variously.

The "socially recognized" nature of property rights as required by the definition above allows us to incorporate the role of those factors that are usually described vaguely as informal, or generally, as cultural. My assumption (2) rests on the idea that the greater the extent to which a right is accepted culturally, the less costly it is to enforce that right.

The notion that constitutional rules are formed by informal rules has been formulated by some of the economists trying to understand constitutions as they are broadly understood. For example, Hayek (1944 [1991]: 159) was greatly worried by the decline of the virtues of "independence and self-reliance, individual initiative and local responsibility, the successful reliance on voluntary activity, non-interference with one's neighbour and tolerance of the different and queer, respect for custom and tradition, and a healthy suspicion of power and authority". He saw these values as the foundations of the freedom of the West. Indeed, in Hayek (1960: 139) he explains that the "recognition" of "individual spheres" is necessary so that individual freedom can be enforced, and this happens through the "acceptance" of general rules. This means, as he (Hayek 1960: 217-218) concludes, that the procedural safeguards of liberty "presuppose for their effectiveness the acceptance of the rule of law", a "political creed which people will defend even when they do not fully understand its significance".

Buchanan (1975 [2000]: 97) also points out the relationship between enforcement costs and the willingness to follow the rules, when saying that "there is a relationship between potential voluntary compliance independent of enforcement-punishment and the resource investment that will be required to attain specified behavioural limits". ${ }^{10}$

The argument of this section breaks down to what can be summarized as a Property Rights Possibility Frontier as illustrated in Figure $1:^{11}$ there is a trade-off between the scope of a nonprohibited class of uses and the level of expropriation which is provided by the government. The rate of this trade-off is set by informal factors. Enforcing a larger scope of the nonprohibited class of uses will require

10 An interesting example of how ethical rules may affect constitutional choice can be found in
Buchanan and Tullock (1962[1999]: 208). They argue that when ethical rules prevent vote trad-
ing, the average citizen - behind the veil of uncertainty - will choose a constitution that puts
more constraints on the majority. The reason is that as a possible member of some minority she
will find it more difficult to make a bargain over her individual rights with the majority that tries
to violate them if ethical rules preventing that bargain are in place.
I thank an anonymous referee for suggesting the development of Figure 1 as well as Table 1 . 


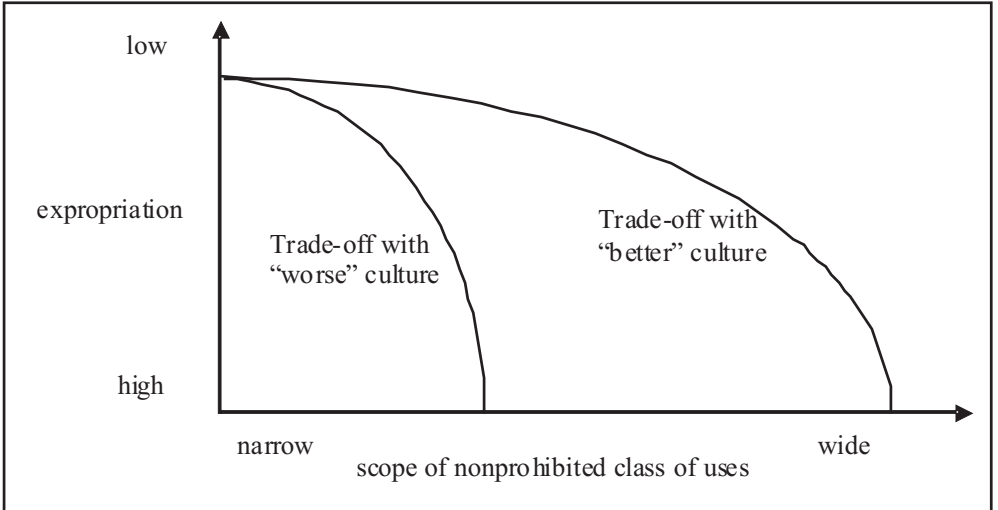

Figure 1. Property Rights Possibility Frontier: Trade-off between expropriation (enforcement of rights) and the scope of rights

more resources which will, of course, require some kind of a tax broadly understood and will increase the level of expropriation. This increase in enforcement costs will be lower if the "social recognition" of the rules to be enforced is larger.

\section{A SIMPLE THEORY OF THE ENFORCEMENT AND THE SCOPE OF PROPERTY RIGHTS}

In the following three subsections I will present a model that is built on the insights acquired in previous sections in the spirit of the property rights school. The argument builds on what was said in the previous two sections. In this spirit the government is modelled as making a decision concerning the scope of nonprohibited class of uses to be enforced and the level of enforcement. It will be demonstrated that whether or not a wide scope of rights are enforced depends on the cost of limiting rent-seeking. ${ }^{12}$ This cost is deemed to result from cultural factors.

The cost of enforcement plays an important role in Barzel's (1989: 84) insights on the abolition of slavery when he says that "[b]y the end of the nineteenth century, slavery had largely been abolished, perhaps because the costs of policing the institutions exceeded its gains." That is, the cost of enforcing the property rights of the slave owners became so high that it did not pay off to enforce them. This suggests that the cost of enforcement is the most important determinant of whether or not an activity is protected by force. However, this quote does not specify whose gain and whose cost matter. In the model discussed in the following three subsections it depends on whether the government is constrained or not. In a somewhat similar argument examining religious liberty Gill (2005) also emphasizes - among other things - on the enforcement costs of religious hegemonies and regulations of entry to the religious market. 


\subsection{Rent seeking and the enforcement of rights}

In what follows I will use different extensions of Murphy et al.'s (1993) model (MSV). The main modification of the MSV model is an introduction of a government which must incur some costs to enforce rights.

There are two types of activities: production and rent seeking. The return on production is $a$ but only an $a-\gamma$ share of it is expropriable by the government. Rent seeking yields a return of $\beta$ and reduces the net return on production by the same amount. In the original MSV model there are three different kinds of equilibria depending on the size of $\beta$ : one with a unique good equilibrium, one with a stable bad and a stable good, and an unstable intermediate equilibrium, and one with a unique bad equilibrium.

For the sake of simplicity I drop the second case and assume that $\gamma=1$ and continue with only two possible cases: strong enforcement of property rights $(a>1>$ $\left.\beta_{s}\right)$ and weak enforcement of rights $\left(\beta_{w}>a>1\right)$. Further I suppose that weak enforcement requires the state to incur a $\operatorname{cost} c$, while strong enforcement requires it to incur a cost of $2 c$.

This cost is the key parameter of the model and also the one I interpret as a measure of culture. Boettke (2012: 150-151) writes for example that,

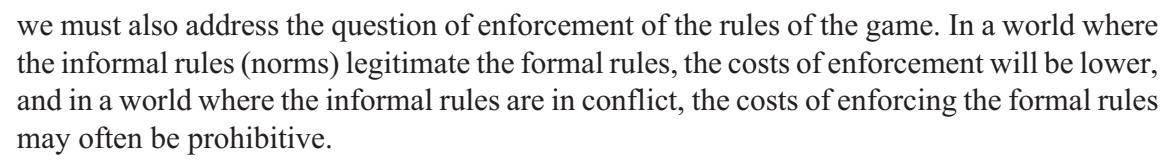
the informal rules (norms) legitimate the formal rules, the costs of enforcement will be lower, and in a world where the informal rules are in conflict, the costs of enforcing the formal rules may often be prohibitive.

Stringham (2011) explains carefully why internal moral constraints are important to maintain a market economy giving this proposition a corroboration that is based on theory, empirical research, and common sense. External constraints, he argues, are not enough to maintain a well functioning market which means that the rules of the market will be more costly to enforce if they are not backed by morals. That is, formal constraints aimed at enforcing market rules will have an easier task if these formal constraints are in line with the moral ones. The parameter $c$ can thus be seen as a measure of the extent to which social norms legitimate the rules of private property by attributing a low payoff to rent seeking.

This relationship between enforcement cost and the attitude toward market exchange can also be derived from Buchanan (1994: 127) whose main point is that "[t]he ordering over goods cannot be separated from the means through which goods are expected to be secured". As a result, once rent seeking as a means is condemned to a larger extent than market exchange as a means, enforcing market rules will be less costly. 
The government can be of two types. It may be a net revenue (rent) maximizing (unconstrained) government that seeks to maximize net total tax and rent, or it may be of a constrained type, in which case it will seek to maximize net income (production minus enforcement cost) of the median voter.

Civil liberties are incorporated through two key assumptions: ${ }^{13}$ providing and enforcing civil liberties (1) increases income and the cost of enforcement in the same proportion and (2) reduces the expropriability of income. These assumptions are of course simplifying but not unreasonable. What underpins the first is the fact that a stronger enforcement of property rights will increase income by providing incentives to apply a better technology and increase productivity. A rise in productivity will increase the marginal product of factors of production, too, by the same proportion if the technological improvement is imagined as an increase in total factor productivity. The second assumption is simply a description of what stronger incentives mean.

A simple way to formulate this is to assume that when providing and enforcing civil liberties, the return on productive activities grows by a factor of $\delta>1$, and so does enforcement cost: it becomes $c \delta$ in the case of weak enforcement and $2 c \delta$ in the case of strong enforcement. However, as a formulation of narrowing expropriability, I assume that when civil liberties are introduced, the non-expropriable level of income increases from 1 to $\delta^{2}$.

The idea behind this assumption is that providing civil liberties means a higher level of commitment to secure property rights by the government. The enforcement of civil liberties - a wide scope of rights - will only be credible if the government can promise not to expropriate such a large share of income as it could with a narrow scope of rights.

Note that all these specifics of the model include the core assumptions I made in section 3. The fact that $\delta>1$ reflects assumption (1) by formulating the idea that a stronger enforcement, which means a lower level of expropriation, provides incentives to produce more. Assumption (2), regarding the stickiness of formal institutions, is captured by the fact that the cost of enforcement is a parameter which can be larger or smaller. Finally, assumption (3) is incorporated by giving the government the possibility to choose between a wide and a narrow scope of rights.

\subsection{Unconstrained government and civil rights}

In this model the government has four options to choose from: strong and weak enforcement of rights which do, or do not, include civil liberties. The provision of

13 For the basic model in which civil liberties are not modelled see the Appendix. 
civil liberties is equivalent with the provision of a wide scope of rights. The payoffs of these four options open to the revenue maximizing government are the following: ${ }^{14}$

(1) civil liberties with strong enforcement:

$$
U_{C L}^{S}=a \delta-\delta^{2}-2 \delta c
$$

(2) civil liberties with weak enforcement:

$$
U_{C L}^{W}=\frac{\delta^{2}(a-\delta)}{a}-\delta c ;
$$

(3) no civil liberties with strong enforcement:

$$
U_{0}^{S}=a-1-2 c
$$

(4) no civil liberties with weak enforcement:

$$
U_{0}^{W}=\frac{a-1}{a}-c .
$$

The key conclusion of the examination of these options is that the unconstrained government will never choose the option of weak enforcement with civil liberties, but the other three options are possible depending on the cost of enforcement (c) and productivity $(a)$.

Proposition 1 The unconstrained government will choose

(1) civil liberties with strong enforcement if

$$
c \leq C_{1} \text { and } \delta+1<a
$$

(2) no civil liberties with strong enforcement if

$$
\begin{aligned}
& \qquad C_{1} \leq c \leq C_{0}^{S 0} \text { and } \delta+1<\text { a or } \\
& \qquad c \leq C_{0}^{S 0} \text { and } 2<a \leq \delta+1 \text { or } \\
& \qquad 0 \leq c \leq C_{2} \text { and } a \leq 2 \text {; } \\
& 14 \text { Remember that the payoff of the government is net tax and rent in this case. See the Appendix } \\
& \text { for the details of the calculation. }
\end{aligned}
$$

Society and Economy 36 (2014) 
(3) no civil liberties with weak enforcement if

3

4

$$
C_{2}<c<C_{0}^{W 0} \text { and } a \leq 2
$$

where $C_{1} \equiv \frac{a-(\delta+1)}{2}, C_{2} \equiv \frac{(a-1)^{2}}{a}, C_{0}^{S 0} \equiv \frac{a-1}{2}, C_{0}^{W 0} \equiv \frac{a-1}{a}$.

Otherwise the government will not incur any cost to enforce the rules of private property.

Proof See the Appendix.

What makes understanding proposition 1 somewhat difficult is that the threshold enforcement cost itself is a function of productivity. Figure 2, an illustration of the proposition, clarifies this. As is clear from Figure 2, below a certain income the unconstrained government will not choose the option of a strong enforcement with civil liberties even if the cost of enforcement is low - a certain level of productivity is needed, too. But the lower the cost of enforcement, the lower is the threshold productivity. If productivity is higher than $\delta+1$, it is only the cost of enforcement that makes the government provide civil rights enforcement.

The main conclusion is that informal institutions (the cost of enforcement) and productivity together determine whether civil liberties will be provided even when the protection of civil liberties is assumed to lead to higher income. The key assumption is the decreasing expropriability of this higher income.

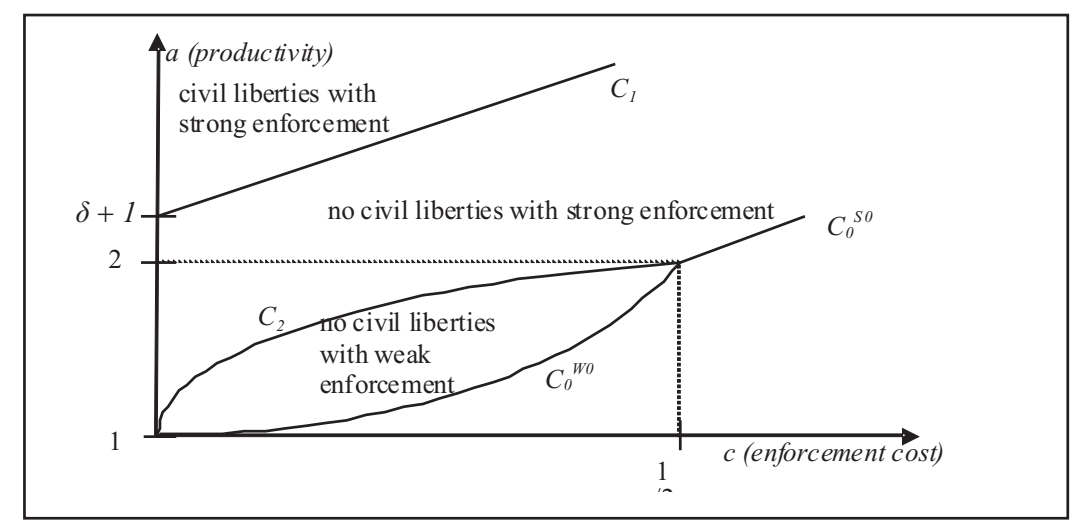

Figure 2. Illustration of proposition 1

Note: The figure incorporates the assumptions that $a>1$ and $\delta>1(\delta+1>2)$. The curves are the graphs of $C_{1}, C_{2}, C_{0}^{W 0}, C_{0}^{S 0}$ as defined in proposition 1. 


\subsection{Constrained government}

In the case of a constrained government the payoffs are the following: ${ }^{15}$

(1) civil liberties with strong enforcement:

$$
U_{C L}^{S}=a \delta-2 \delta c
$$

(2) civil liberties with weak enforcement:

$$
U_{C L}^{W}=\delta^{2}-\delta c
$$

(3) no civil liberties with strong enforcement:

$$
U_{0}^{S}=a-2 c
$$

(4) no civil liberties with weak enforcement:

$$
U_{0}^{W}=1-c
$$

Proposition 2 The constrained government will choose

(1) civil liberties with strong enforcement if

$$
\begin{aligned}
& a>2 \delta \text { and } c<K_{0}^{S C L} \text { or } \\
& 2 \delta>a>1 \text { and } c<K_{1} ;
\end{aligned}
$$

(2) civil liberties with weak enforcement if

$$
2 \delta>a>1 \text { and } K_{1}<c<\delta
$$

where $K_{1} \equiv a-\delta, K_{2} \equiv \frac{a \delta-1}{2 \delta-1}, K_{3} \equiv \frac{a-\delta^{2}}{2-\delta}, K_{0}^{S C L} \equiv \frac{a}{2}$.

Proof See the Appendix.

15

Remember that the constrained government is assumed to be as "democratic" as possible and it is assumed to maximize the net income of the median voter which, in this simple model, is equal to the average net income. "Net" here means net of enforcement costs. 
The case of the constrained government is simpler than that of the unconstrained one but again the thresholds are not independent of the income of productive activities, as illustrated in Figure 3. The constrained government will always provide civil rights but will not always enforce them strongly. Whether it does or not depends on the cost of enforcement and productive income at the same time. Below a certain level of income $(\delta)$ the government will not choose the option of a strong enforcement, while above that the informal factors represented by the cost of enforcement are the key.

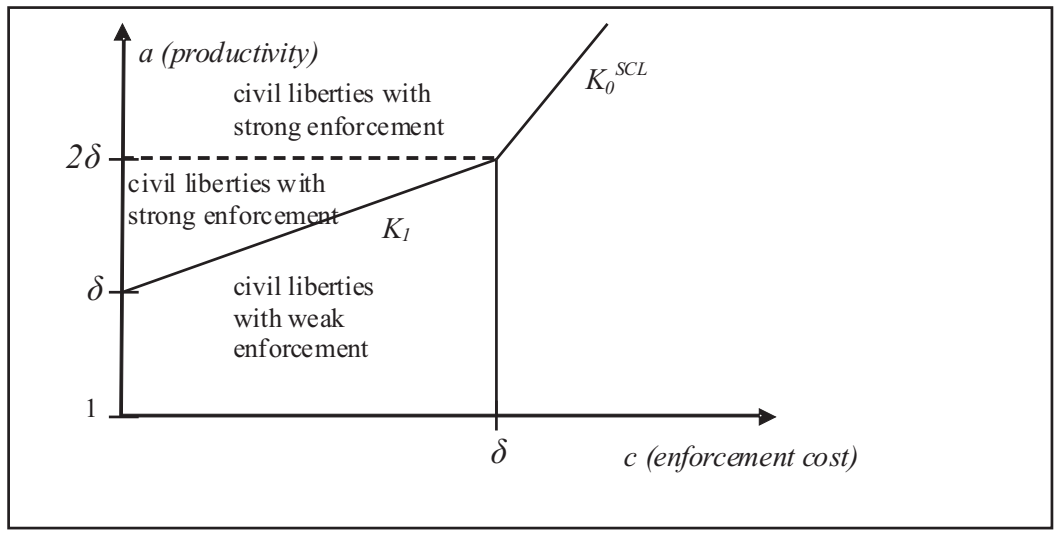

Figure 3. Illustration of proposition 2

Note: The figure incorporates the assumptions that $a>1$ and $\delta>1(\delta+1>2)$. The curves are the graphs of $K_{1}, K_{0}^{S C L}$ as defined in proposition 2 .

\section{PREDICTIONS CONCERNING INCOME DIFFERENCES}

The model predicts that income levels will depend on the scope of rights and the enforcement of rights as shown in Table 2.

Table 2

Predictions of the model concerning per capita income with different definition and assignment of rights

\begin{tabular}{llcc}
\hline & & weak & strong \\
\hline $\begin{array}{l}\text { Scope of non-prohibited } \\
\text { class of uses }\end{array}$ & narrow & 1 & $a$ \\
wide & $\delta^{2}$ & $a \delta$ \\
\hline
\end{tabular}


$1 \quad$ Because of the assumptions of the model $\delta^{2}>1$ and $a>1$ (see section 4.1), and 2 it is reasonable to assume, that $a \delta>\delta^{2}(a>\delta)$. These three assumptions simply 3 mean that gross income (which includes the cost of enforcement) increases if a 4 wider scope of rights are enforced with the same level of enforcement (level of ex5 propriation), or if the same scope of rights are enforced with a stronger enforce6 ment. To put it differently, when costs of enforcement are not considered, a wider 7 scope of rights or a higher level of their enforcement will increase income.

8 Propositions 1 and 2 in section 4 give some guidance regarding the probabili9 ties with which a country will provide a wide or narrow scope of rights and 10 whether it will enforce it weakly or strongly. The main messages of the two propo11 sitions are included in Tables 3 and 4. Table 3 shows these probabilities for the un12 constrained government while Table 4 shows the same for the constrained one.

\section{Table 3}

Probabilities of providing narrow/wide scope of rights with weak/strong enforcement for the unconstrained government

\begin{tabular}{llcc}
\hline & & Enforcement of non-prohibited class of uses \\
\hline Scope of non-prohibited & narrow & weak & strong \\
class of uses & wide & $1-\pi_{N S}^{U}-\pi_{W S}^{U}$ & $\pi_{N S}^{U}$ \\
\hline
\end{tabular}

Table 4

Probabilities of providing narrow/wide scope of rights with weak/strong enforcement for the constrained government

\begin{tabular}{llcc}
\hline & & Enforcement of non-prohibited class of uses \\
\hline $\begin{array}{l}\text { Scope of non-prohibited } \\
\text { class of uses }\end{array}$ & $\begin{array}{l}\text { narrow } \\
\text { wide }\end{array}$ & 0 & strong \\
\hline
\end{tabular}

Table 3 includes the result of proposition 1 according to which an unconstrained government will not provide a wide scope of rights with weak enforcement, while Table 4 includes the result of proposition 2 according to which a constrained government will always provide a wide scope of rights.

Using the probabilities in Tables 3 and 4 it is possible to derive the condition under which the provision of civil liberties have a larger "effect" on income than the constraint on executives does. Consider the expected income in a country with a constrained and an unconstrained government: 
$E(y \mid$ government is constrained $)=\pi_{W S}^{C} a \delta+\left(1-\pi_{W S}^{C}\right) \delta^{2}$,

$E(y \mid$ government is unconstrained $)=\pi_{W S}^{U} a \delta+\pi_{N S}^{U} a+\left(1-\pi_{W S}^{U}-\pi_{N S}^{U}\right) \times 1$.

The difference between the two expected incomes above gives the prediction concerning the effect of constraint on executives:

$\Delta_{E C}=E(y \mid$ government is constrained $)-E(y \mid$ government is unconstrained $)=$

$$
=\left(\pi_{W S}^{C}-\pi_{W S}^{U}\right) a \delta+\left(1-\pi_{W S}^{C}\right) \delta^{2}-\pi_{N S}^{U}(a-1)-\left(1-\pi_{W S}^{U}\right) .
$$

Similarly, it is possible to derive the expected income difference that is associated with the presence of civil liberties as opposed to the lack of it by considering first the conditional expectations of income:

$$
\begin{aligned}
& \begin{aligned}
E(y \mid \text { civil liberties are provided })= & \pi_{U / W}\left[\pi_{W S}^{U} a \delta+0 \delta^{2}\right]+ \\
+ & \left(1-\pi_{U / W}\right)\left[\pi_{W S}^{C} a \delta+\left(1-\pi_{W S}^{C}\right) \delta^{2}\right], \\
E(y \mid \text { civil liberties are not provided })= & \pi_{U / W}\left[\pi_{N S}^{U} a+\left(1-\pi_{N S}^{U}-\pi_{W S}^{U}\right]+\right. \\
& +\left(1-\pi_{U / N}\right)[0 \times a+0 \times 1],
\end{aligned}
\end{aligned}
$$

where $\pi_{U / W}$ is the probability that the government is unconstrained if civil liberties are provided, while $\pi_{U / N}$ is the probability that the government is unconstrained if civil liberties are not provided. The Bayes rule allows us to derive that

$$
\pi_{U / W}=\frac{\pi_{W S}^{U} \pi_{U}}{\pi_{W S}^{U} \pi_{U}+\left(1-\pi_{U}\right)} \text { and } \pi_{U / N}=1 \text {, }
$$

where $\pi U$ is the probability that a country has an unconstrained government.

Using (12), (13), and (14) gives the "prediction" concerning the "effect" of civil liberties:

$$
\Delta_{C L}=E(y \mid \text { civil liberties are provided })-E(y \mid \text { civil liberties are not provided })=
$$$$
=\left[\pi_{W / U} \pi_{W S}^{U}+\left(1-\pi_{W / U}\right) \pi_{W S}^{C}\right] a \delta+\left(1-\pi_{W / U}\right)\left(1-\pi_{W S}^{C}\right) \delta^{2}-\pi_{N S}^{U}(a-1)-\left(1-\pi_{W S}^{U}\right) .
$$

Comparing (15) and (11) leads to the following proposition. 


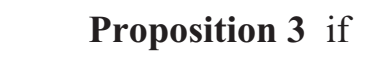

Proof See the Appendix.

Proposition 3 says that civil liberties provision will have a larger effect on expected income than executive constraints if the probability that a country has an unconstrained government is below a threshold level. The threshold is set by the parameter of the model. Most importantly, bearing in mind that $a>\delta$, the threshold is decreasing in $\pi_{W S}^{C}$ and increasing in $\pi_{W S}^{U}$. That is, the threshold is lower if the constrained government is more probable to provide a wide scope of rights with strong enforcement and it is higher if the unconstrained government is more probable to provide a wide scope of rights with strong enforcement.

It is also interesting to note that the provision of wide scope of rights (civil liberties) is a better predictor of a strong enforcement of rights than constraints on executives are. To see this, consider that the probability that a constrained government will apply a strong enforcement is $\pi_{W S}^{C}$, while the probability that a government that provides a wide scope of rights will apply a strong enforcement is

$$
\left(1-\pi_{U}\right) \pi_{W S}^{C}+\pi_{U}=\pi_{W S}^{C}+\pi_{U}\left(1-\pi_{W S}^{C}\right) .
$$

Clearly, this latter probability is larger than the former until $\pi_{W S}^{C}<1$. This conclusion is in line with BesYishay and Betancourt's (2010) suggestion according to which the provision of civil liberties is a better indicator of the government's commitment to maintain the rule of law than is the constraint on executives.

\section{CONCLUSION}

Individual freedom is the most important determinant of economic development. It is not only a libertarian conviction but a fact supported by a large number of empirical results. However, as I argued in this paper individual freedom includes two constitutional decisions. Property rights need to be defined first, and then they need to be enforced. A strong enforcement of a wide scope of property rights is what possibly leads to the highest development as opposed to a weak enforcement or a narrow scope of rights. 
There are two reasons why constraints on executives are an imperfect indicators of providing and strongly enforcing a wide scope of rights. One reason is that even an unconstrained government can decide to provide and to strongly enforce a wide scope of property rights. The second is that even if the government is constrained, it may not strongly enforce a wide scope of property rights.

The imperfect association between constrained government and strong enforcement of a wide scope of rights can be explained by, as I have argued in the paper, culture and technology. Culture determines the cost of enforcing, and technology determines the income that can be generated by a strong enforcement of property rights. As a result, culture and technology determines the payoffs of strongly enforcing a wide scope of rights for the rent seeking government as well as for the median voter.

Putting these pieces together we have an explanation that helps us understand the fact that the level of civil freedoms is a better predictor of development than is the level of the constraint on executives.

This paper has thus given an explanation for the cross-country pattern identified by BenYishay and Betancourt (2010). No very specific, if any, policy conclusions can be derived from such a result. I would rather emphasize three broad ones. First, the argument suggests that the (political) argument for economic and civil freedoms should not be separated in the sense that economic freedom is important for material welfare while civil freedoms are important from an immaterial (moral) point of view. Rather the same moral or instrumental argument can be used in both cases.

Second, culture has been defined here as those informal factors that determine the costs of enforcement of the rules of freedom. This does not imply that such factors can only change in the very long run, although culture is usually understood in this way. Whether the informal factors behind civil freedoms and growth can change relatively quickly is a very interesting question for possible future research which seems to be crucial for answering the "big question" as to how economic development can be fostered. ${ }^{16}$

Third, this paper casts some doubt on those theories and especially those policy proposals (Freedom House 2012) that emphasize the causality running from the constraints on executives to "good" outcomes, primarily economic development, and that suggest accordingly that these outcomes can be reached by political pressure from outside.

16 An anonymous referee raised the important issue as to why the cost of enforcement can change within a country, too. My model does not imply anything that would answer that question if admitting the possibility of their variability is left aside. The possibility of a relatively quick change in informal factors can be an answer to that - and a very important and difficult - issue for further research. 
3 The government's decision in the basic model of section 4

4 Unconstrained government

6 In the case of strong enforcement $\left(a>1>\beta_{s}\right)$ the ratio of rent-seekers to producers

7 will be 0 in equilibrium and the government can tax away the income above 1 .

8 Consequently its net revenue is

$$
a-1-2 c
$$

In the case of weak enforcement $\left(\beta_{w}>a>1\right)$ rent-seeking has a return of $\beta_{w}$ until the return of production $\left(a-\beta_{w} n\right)$ reaches its minimum, 1 , that is until $n<\frac{a-1}{\beta_{w}}$. Consequently, in equilibrium the ratio of the number of rent-seekers to that of producers will satisfy the equation

$$
\frac{a-1}{n^{*}}=1
$$

that is,

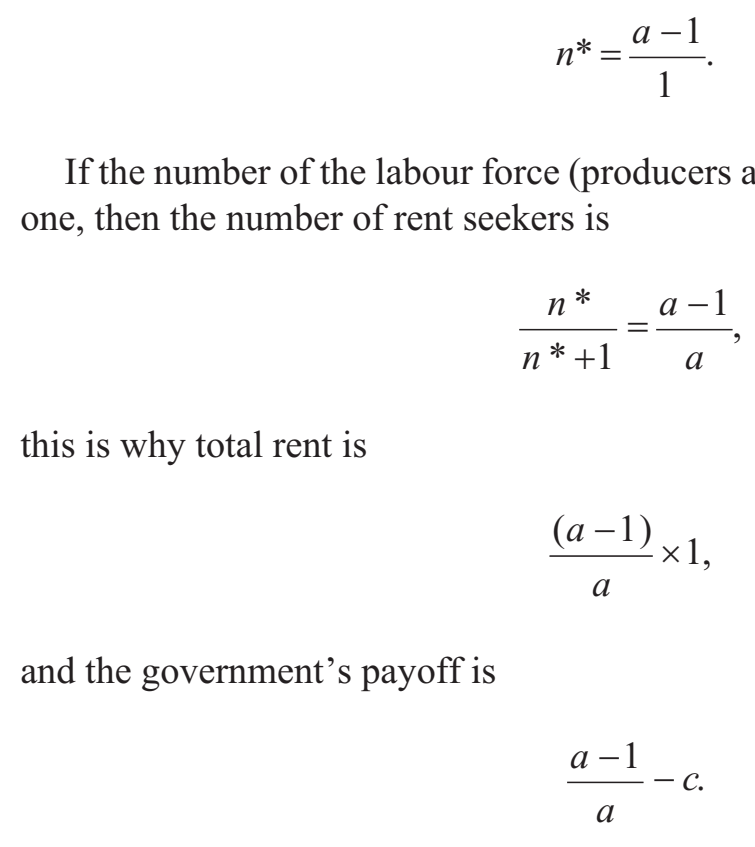$$
n^{*}=\frac{a-1}{1}
$$
one, then the number of rent seekers is

this is why total rent is

$$
\frac{n^{*}}{n^{*}+1}=\frac{a-1}{a}
$$

$$
\frac{(a-1)}{a} \times 1
$$

and the government's payoff is

$$
\frac{a-1}{a}-c
$$

If the number of the labour force (producers and rent seekers) is normalized to 


\section{Constrained government}

2

3 The case of the constrained government is straightforward. The payoffs are shown 4 in an organized way in Table 5. The payoffs can be calculated in the same way in

Table 5

The payoff of the government under different regimes and enforcement in the basic model

\begin{tabular}{lcc} 
& Constrained government & Unconstrained government \\
\hline Strong enforcement & $a-2 c$ & $a-1-2 c$ \\
Weak enforcement & $1-c$ & $\frac{a-1}{a}-c$ \\
\hline
\end{tabular}

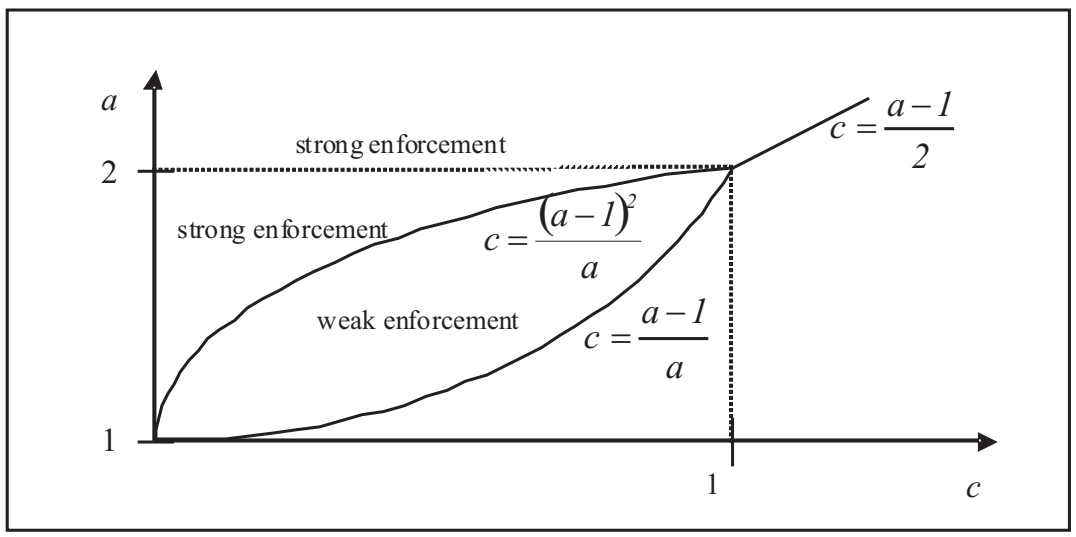

Figure 4. Strong and weak enforcement of rights under unconstrained government in the basic model

Note: The figure incorporates the assumptions that $a>1$.

Comparing the payoffs makes it clear that a revenue maximizing government will choose strong enforcement if

$$
c \leq \frac{(a-1)^{2}}{a} \text { and } c \leq \frac{a-1}{2},
$$

otherwise it will choose weak enforcement provided that

$$
c<\frac{a-1}{a} \text {. }
$$




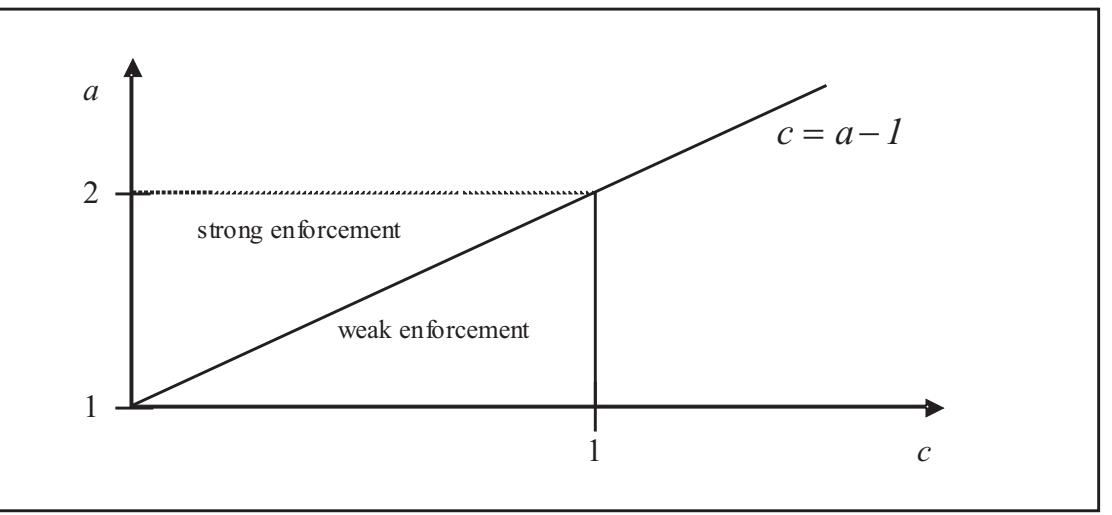

Figure 5. Strong and weak enforcement of rights under constrained government in the basic model

Note: The figure incorporates the assumptions that $a>1$.

A constitutional government will choose strong enforcement if

$$
c<a-1
$$

Otherwise it will choose weak enforcement until $c<1$.

These results make it clear that the choice between strong and weak enforcement will depend on the type of government, the cost of enforcement, and the income of the productive activities. These solutions are summarized in Figures 4 and 5 .

\section{Proof of Proposition 1}

Consider the four possible cases of property rights enforcement.

(1) The government chooses civil liberties with strong enforcement (S-CL) if the conditions

$$
U_{C L}^{S}>U_{C L}^{W}, U_{C L}^{S}>U_{0}^{S}, U_{C L}^{S}>U_{0}^{W}, U_{C L}^{S}>0
$$

all hold. These conditions can be summarized as

$$
c<\min \left(C_{1}, C_{3}, C_{6}, C_{0}^{S C L}\right),
$$




$$
\begin{aligned}
& \text { where } C_{1} \equiv \frac{a-(\delta+1)}{2}, C_{3}=\frac{(a-\delta)^{2}}{a}, C_{6}=\frac{a \delta(a-\delta)-(a-1)}{a(2 \delta-1)}, C_{0}^{S C L}=\frac{a-d}{2} \delta . \\
& \text { With some calculation it can be shown that } \\
& \qquad C_{0}^{S C L}-C_{1}=\frac{1}{2} \\
& \qquad C_{6}-C_{1}=\frac{1}{2 a(2 \delta-1)}\left[a^{2}-(3-\delta) a+2\right] \\
& \qquad C_{3}-C_{1}=\frac{1}{2}\left[a^{2}-(3 \delta-1) a+2 \delta^{2}\right] .
\end{aligned}
$$

None of the three differences can be positive because of the assumptions regarding $a$ and $\delta$. This means that $c<\min \left(C_{1}, C_{3}, C_{6}, C_{0}^{S C L}\right)=C_{1}$.

Obviously it is only possible to satisfy this condition if $C_{1}$ is positive, that is, if

$$
a>\delta+1
$$

(2) The government will never choose civil liberties with weak enforcement.

To show this, suppose that the government chooses this option. In that case notice first that four conditions would have to be satisfied:

$$
U_{C L}^{W}>U_{C L}^{S}, U_{C L}^{W}>U_{0}^{S}, U_{C L}^{W}>U_{0}^{W}, U_{C L}^{W}>0
$$

These would require the cost of enforcement to satisfy the condition

$$
\max \left(C_{2}, C_{4}\right) \leq c \leq \min \left(C_{5}, C_{0}^{W C L}\right),
$$

where

$$
\begin{aligned}
& C_{2} \equiv \frac{(a-1)^{2}}{a}, C_{4} \equiv \frac{a(a-1)-\delta^{2}(a-\delta)}{a(2-\delta)}, \\
& C_{5} \equiv \frac{\delta^{2}(a-\delta)-(a-1)}{a(\delta-1)}, C_{0}^{W C L} \equiv \frac{\delta(a-\delta)}{a} .
\end{aligned}
$$


But this condition cannot be satisfied because one can show that: $C_{0}^{W C L}<C_{4}$ :

$$
C_{0}^{W C L}-C_{4} \equiv \frac{1}{a(2-\delta)}\{(a-\delta)[-2 \delta(\delta-1)-a(a-1)]\}<0
$$

That is, the condition (19) above will never hold.

(3) The government will choose no civil liberties with strong enforcement if all of the following conditions hold at the same time:

$$
U_{0}^{S}>U_{C L}^{S}, U_{0}^{S}>U_{C L}^{W}, U_{0}^{S}>U_{0}^{W}, U_{0}^{S}>0
$$

These are true if

$$
\min \left(C_{1}, 0\right) \leq c \leq \min \left(C_{2}, C_{4}, C_{0}^{S 0}\right)
$$

where

$$
C_{1} \equiv \frac{a-(\delta+1)}{2}, C_{2} \equiv \frac{(a-1)^{2}}{a}, C_{4} \equiv \frac{a(a-1)-\delta^{2}(a-\delta)}{a(2-\delta)}, C_{0}^{S 0} \equiv \frac{a-1}{2} .
$$

It is possible to show that $\min \left(C_{2}, C_{4}, C_{0}^{S 0}\right)=C_{0}^{S 0}$ if $y>2$. Consider that both the difference

$$
C_{2}-C_{0}^{S 0}=\frac{(a-1)(a-2)}{2 a}
$$

and the difference

$$
C_{4}-C_{0}^{S 0}=\frac{1}{2 a}(2-\delta)\left[a(a-2)+a \delta^{2}+a \delta+2 \delta^{3}\right]
$$

are positive under the condition $a>2$.

$$
\text { However, when } a \leq 2, \min \left(C_{4}, C_{6}, C_{0}^{S 0}\right)=C_{2} \text {, because }
$$

$$
C_{2}-C_{0}^{S 0}=\frac{(a-1)(a-2)}{2 a}<0
$$

and the difference 


$$
C_{4}-C_{0}^{S 0}=\frac{1}{2 y}(2-\delta)\left[a^{2}+\left(\delta^{2}+\delta-2 a\right) a+2 \delta^{3}\right]
$$

is positive. This implies that

$$
C_{2}<C_{0}^{S 0}<C_{4}
$$

In addition, if $a \leq 2$, then $C_{1} \leq 0$, which implies that the condition (21) will take the form of

$$
0 \leq c \leq C_{2} .
$$

(4) The government will choose no civil liberties with weak enforcement if

$$
U_{0}^{W}>U_{C L}^{S}, U_{0}^{W}>U_{C L}^{W}, U_{0}^{W}>U_{0}^{S}, U_{0}^{W}>0
$$

To show that the conditions formulated in the proposition below must hold so that these four inequalites must be satisfied, note that if $\max \left(C_{2}, C_{5}, C_{6}\right)<C_{0}^{W}$, choosing this option will not pay off under any condition. But with some algebraic manipulation it is possible to derive that

$$
\begin{aligned}
& C_{0}^{W}-C_{2}=-\frac{(a-1)(a-2)}{a} \text { which is positive if } a<2 ; \\
& C_{0}^{W}-C_{5}=\frac{\delta(\delta-1)}{a}(\delta+1-a) \text { which is positive if } a<\delta+1 \\
& C_{0}^{W}-C_{5}=-\frac{\delta}{a(2 \delta-1)}\left[a^{2}-(\delta+2)+2\right] \text { which is positive if } \\
& a<\frac{\delta+2+\sqrt{(\delta+2)^{2}-8}}{2} \text { and } a>\frac{\delta+2-\sqrt{(\delta+2)^{2}-8}}{2}
\end{aligned}
$$

All three conditions are satisfied if $1<a<2$.

On the other hand, it is possible to show that $\max \left(C_{2}, C_{5}, C_{6}\right)=C_{2}$. First, consider that

$$
C_{2}-C_{5}=\frac{(a-1)^{2}}{a}-\frac{\delta^{2}(a-\delta)-(a-1)}{a(\delta-1)}=\frac{(a-1)^{2}-(\delta+1)(a-1)+\delta^{2}}{a},
$$

that is

$C_{2}-C_{5}=\frac{(a-1-\delta)^{2}+2 \delta(a-1)-(\delta+1)(a-1)}{a}=\frac{(a-1-\delta)^{2}+(\delta-1)(a-1)}{a}$

which is positive under the assumptions we made. 


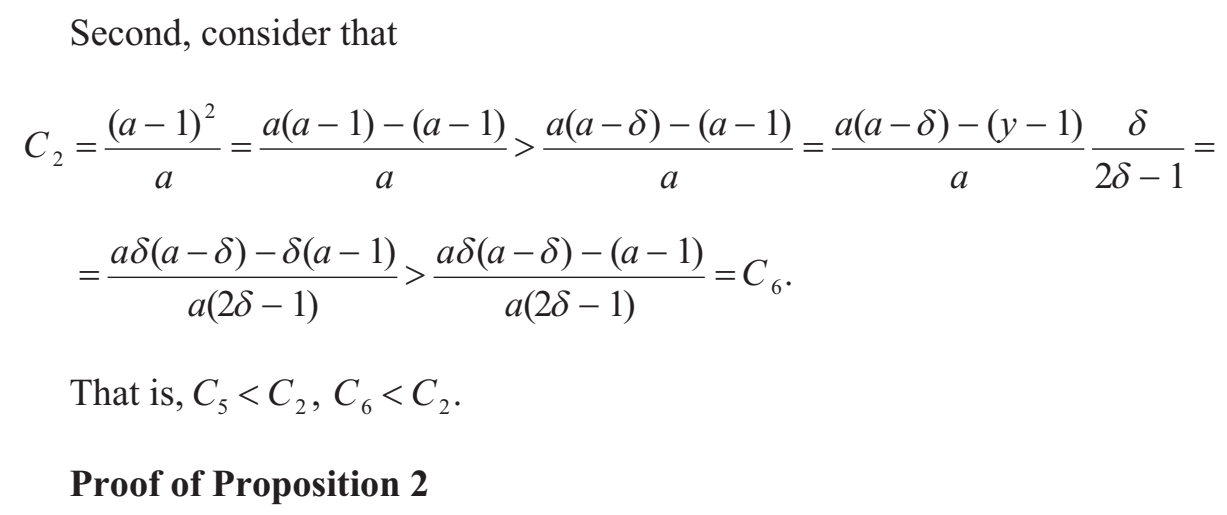

Again, we will consider the four possible cases in turn.

(1) The government chooses civil liberties with strong enforcement (S-CL) if the conditions

16

$$
U_{C L}^{S}>U_{C L}^{W}, U_{C L}^{S}>U_{0}^{S}, U_{C L}^{S}>U_{0}^{w}, U_{C L}^{S}>0
$$

all hold. This implies that the following equalities must hold:

$$
c<K_{1}, \delta>1, c<K_{2}, c<K_{0}^{S C L}
$$

which can be summed up as

$$
c<\min \left(K_{1}, K_{2}, K_{0}^{S C L}\right),
$$

since $\delta>1$ is true by definition. Further, seeing that

$$
\begin{gathered}
K_{1}-K_{2}=\frac{a \delta-a-2 \delta^{2}+\delta+1}{2 \delta-1}, \\
K_{1}-K_{0}^{S C L}=a / 1-\delta, \text { and } \\
K_{2}-K_{0}^{S C L}=\frac{a \delta-1}{2 \delta-1}-\frac{a}{2}=\frac{a-2}{2(2 \delta-1)},
\end{gathered}
$$

it follows that

$$
\min \left(K_{1}, K_{2}, K_{0}^{S C L}\right)=\left\{\begin{array}{l}
K_{0}^{S C L}, \text { if } a>2 \delta \\
K_{1}, \text { if } 2 \delta>a>1
\end{array} .\right.
$$


(2) The government will choose civil liberties with weak enforcement if

$$
U_{C L}^{W}>U_{C L}^{S}, U_{C L}^{W}>U_{0}^{S}, U_{C L}^{W}>U_{0}^{W}, U_{C L}^{W}>0
$$

These imply in turn that

$$
c>K_{1}, c>\frac{a-\delta^{2}}{2-\delta} \equiv K_{3}, c<\delta+1 \equiv K_{4} \text {, and } c<\delta \equiv K_{0}^{W C L} .
$$

Again, it is useful to write the sum of these conditions as

$$
\max \left(K_{1}, K_{3}\right)<c<\delta .
$$

Using the same method as before, consider the difference

$$
K_{1}-K_{3}=a-\delta-\frac{a-\delta^{2}}{2-\delta}=\frac{1}{2-\delta}[(\delta-1)(2 \delta-a)] .
$$

This implies that

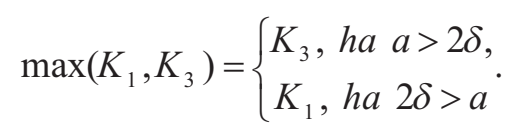

Further, since

$$
\delta-K_{3}=\delta-\frac{a-\delta^{2}}{2-\delta}=-\frac{a-2 \delta}{2-\delta},
$$

this option will not be chosen if $y>2 \delta$, while

$$
\delta-K_{1}=\frac{1}{2 \delta-1}\left[-\delta(a+1)+a-1+\delta d^{2}\right]
$$

will be positive until $a<2 \delta+1$.

(3) The government will never choose no civil liberties with strong enforcement

If it were chosen all of the following conditions would have to hold

$$
U_{0}^{S}>U_{C L}^{S}, U_{0}^{S}>U_{C L}^{S}, U_{0}^{S}>U_{0}^{W}, U_{0}^{S}>0
$$


1 But the first condition cannot be satisfied because that would apply that $\delta<1$ which is not possible by definition.

(4) The government will never choose no civil liberties with weak enforcement. Again the four conditions

$$
U_{0}^{W}>U_{C L}^{S}, U_{0}^{W}>U_{C L}^{W}, U_{0}^{W}>U_{0}^{S}, U_{0}^{W}>0
$$

cannot hold together because the third one is identical with the condition that $c>\delta$

+1 while the fourth one is the same as requiring that $c<1$ which clearly cannot be true at the same time.

\section{Proof of Proposition 3}

where

Use equations (11), and (15) to derive that

$$
\Delta_{C L}-\Delta_{E C}=\pi_{W / U}\left[\left(\pi_{W S}^{U}-\pi_{W S}^{C}+\frac{\pi_{W S}^{U}}{\pi_{W / U}}\right) a \delta-\left(1-\pi_{W S}^{C}\right) \delta^{2}\right],
$$

Acemoglu, D. - Johnson, S. (2005): Unbundling Institutions. Journal of Political Economy 113(5):

$$
\frac{\pi_{W S}^{U}}{\pi_{W / U}}=\frac{1}{\pi_{U}}-1+\pi_{W S}^{U}
$$

because of (14).

With $\pi_{W / U}$ being positive, $\Delta_{C L}-\Delta_{E C}>0$ if the expression in square brackets in (24) is positive.

Substituting (25) into (24) and making some algebraic manipulations leads to proposition 3.

Acemoglu, D. - Johnson, S. - Robinson, J. (2005): Institutions as the Fundamental Cause of Long-Run Growth. In: Aghion, Ph. - Durlauf, S. N (eds): Handbook of Economic Growth, Volume 1A. The Netherlands: Elsevier, pp. 385-472. opment: An Empirical Investigation. American Economic Review 91(5): 1369-1401. 
Acemoglu, D. - Johnson, S. - Robinson, J. A. - Yared, P. (2005a): From Education to Democracy? American Economic Review 95(2): 44-49.

Acemoglu, D. - Johnson, S. - Robinson, J. A. - Yared, P. (2005b): Income and Democracy. NBER Working Paper No. 11205.

Acemoglu, D. - Robinson, J. A. (2006): Economic Backwardness in Political Perspective. American Political Science Review 100(1): 115-131.

Alchian, A. A. (1977 [1965]): Some Economics of Property Rights. In: Alchian. A. (ed.) Economic Forces at Work. Collected Works by Armen A. Alchian. Indianapolis: Liberty Press, pp. 127-149.

Alchian, A. A. - Demsetz, H. (1973): The Property Right Paradigm. Journal of Economic History 33(1): 16-27.

10 Barro, R. J. (1996): Democracy and Growth. Journal of Economic Growth 1(1): 1-27.

11 Barzel, Y. (1989): An Economic Analysis of Property Rights. Cambridge: The Cambridge University Press.

BenYishay, A. - Betancourt, R. (2010): Civil Liberties and Economic Development. Journal of Institutional Economics 6(3): 281-304.

Blume, L. - Voigt, S. (2007): The Economic Effects of Human Rights. Kyklos 60(4): 509-538.

Boettke, P. J. (2012): Living Economics: Yesterday, Today, and Tomorrow. Oakland: The Independent Institute in Cooperation with Universidad Francisco Marroquin.

Buchanan, J. M. (2000 [1975]): The Limits of Liberty: Between Anarchy and Leviathan (The Collected Works of James Buchanan, Volume 7). Library of Economics and Liberty. Indianapolis: Liberty Fund.

Buchanan, J. M. (1994): Choosing What to Choose. Journal of Institutional and Theoretical Economics 150(1): 123-135.

Buchanan, J. - Tullock, G. (1999[1962]): The Calculus of Consent: Logical Foundations of Constitutional Democracy. Indianapolis: Liberty Fund.

Congleton, R. D. (2011): Perfecting Parliament. Constitutional Reform, Liberalism, and the Rise of Western Democracy. Cambridge: Cambridge University Press.

Czegledi, P. (2012): Szabadságjogok és gazdasági szabadság - a gazdasági növekedés két különböző tényezője? [Civil liberties and economic freedom - Two different factors of economic development?] E-conom 1(2): 2-13.

Director, A. (1964): The Parity of the Economic Market Place. Journal of Law and Economics 7(Oct.): $1-10$.

Easterly, W. - Levine, R. (2012): The European Origins of Economic Development. NBER Working Paper 18162.

Easton, S. T. - Walker, M. A. (1997): Income, Growth, and Economic Freedom. American Economic Review 87(2): 328-332.

Freedom House (2012): Freedom in the World. Country Ratings and Status. Territory Ratings and Status. http://www.freedomhouse.org/report-types/freedom-world

Gill, A. (2005): The Political Origins of Religious Liberty: A Theoretical Outline. Interdisciplinary Journal of Research of Religion 1(1), Article 1.

Gleaser, E. L. - La Porta, R. - Lopez-De-Silanes, F. - Shleifer, A. (2004): Do Institutions Cause Growth? Journal of Economic Growth 9(3): 271-303.

36 Gwartney, J. - Lawson, R. - Hall, J. (2012): Economic Freedom of the World 2012 Annual Report. Vancouver, Canada: The Fraser Institute.

Gwartney, J. - Lawson, R. (2003): The Concept and Measurement of Economic Freedom. European Journal of Political Economy 19(3): 405-430.

39 Hayek, F. A. (1991 [1944]): The Road to Serfdom. London: Routledge.

40 Hayek, F. A. (1960): The Constitution of Liberty. Chicago: University of Chicago Press. 
1 Knight, F. (1922): Ethics and the Economic Interpretation. Quarterly Journal of Economics 36(3): 454-481.

Kozenkow, J. (2013): New Institutional Economics: Foundations and Latest Trends. Society and Economy 35(1): 87-101.

Lipset, S. M. (1959): Some Social Requisites of Democracy: Economic Development and Political Legitimacy. American Political Science Review 53(1): 69-105.

McCloskey, D. N. (2010): Bourgeois Dignity. Why Economics Can't Explain the Modern World. Chicago:The University of Chicago Press.

McCloskey, D. N. - Klamer, A. (1995): One Quarter of GDP is Persuasion. American Economic Review 85(2): 191-195.

Miller, T. - Holmes, K. R. - Feulner, E. J. (2012): 2012 Index of Economic Freedom. Washington and New York: The Heritage Foundation and Dow Jones \& Company, Inc.

Murphy, K. M. - Shleifer, A. - Vishny, R. W. (1993): Why is Rent-Seeking so Costly to Growth. American Economic Review 83(2): 409-414.

Murtin, F. - Wacziarg, R. (2012): The Democratic Transition. WP http://www.anderson.ucla.edu/ faculty_pages/romain.wacziarg/downloads/transition.pdf; accessed: 4 July 2013.

Nickel, J. (2013): Human Rights. In: Zalta, N. (ed.), The Stanford Encyclopedia of Philosophy Spring 2013 Edition. http://plato.stanford.edu/archives/spr2013/entries/rights-human/. Accessed 20 December, 2012.

North, D. C. - Weingast, B. R. (1989): Constitutions and Commitment: The Evolution of Institutions Governing Public Choice in Seventeenth-Century England. Journal of Economic History 49(4): 803-832.

Paldam, M. (2007): The Big Pattern of Democracy: A Study of the Gastil Index. In: Marciano, A. Josselin, J.-M. (eds), Democracy, Freedom and Coercion: A Law and Economics Approach. Cheltenham: Edward Elgar, pp. 103-129.

Paldam, M. - Gundlach, E. (2008): Two Views on Institutions and Development: The Grand Transition vs. the Primacy of Institutions. Kyklos 61(1): 65-100.

Paldam, M. - Gundlach, E. (2012): The Democratic Transition: Short-run and Long-run Causality Between Income and the Gastil Index. European Journal of Development Research 24(1): 144-68.

Sen, A. K. (1999): Development as Freedom. New York: Alfred A. Knopf, Inc.

Sobel, R. S. - Coyne, C. J. (2011): Cointegrating Institutions: The Time-Series Properties of Country Institutional Measures. Journal of Law and Economics 54(2): 111-134.

Storr, V. H. (2008): The Market as a Social Space: On the Meaningful Extraeconomic Conversation That Can Occur in Markets. Review of Austrian Economics 21(2-3): 135-150.

Stringham, E. P. (2011): Embracing Morals in Economics: The Role of Internal Moral Constraints in a Market Economy. Journal of Economic Behavior \& Organization 78(1-2): 98-109.

Tabellini, G. (2010): Culture and Institutions: Economic Development in the Regions of Europe. Journal of the European Economic Association 8(4): 677-716.

United Nations (1948): Universal Declaration of Human Rights. http://www.un.org/en/documents/udhr/index.shtml. Accessed 20 August, 2012.

Vanberg, V. (2001). Markets and Regulation. The Contrast Between Free-market Liberalism and Constitutional Liberalism. In: Vanberg, V. (ed.): The Constitution of Markets. London: Routledge, pp. 17-36. 